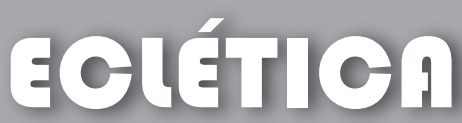 química
}

\section{SYNTHESIS, CHARACTERIZATION AND THERMAL BEHAVIOUR OF HEAVY TRIVALENT LANTHANIDE MALONATES}

\author{
J. R. Locatelli ${ }^{1}$, C. T. Carvalho ${ }^{2}$, F. J. Caires ${ }^{3}$, M. Ionashiro ${ }^{30}$ \\ ${ }^{1}$ Academia da Força Aérea (AFA), Pirassununga, SP, Brazil. \\ ${ }^{2}$ Universidade Federal da Grande Dourados, CEP 79.804-970, Dourados, MS, Brazil. \\ ${ }^{3}$ Instituto de Química, UNESP, CP 355, 14801-970, Araraquara, SP, Brazil
}

\begin{abstract}
Solid-state Ln-L compounds, where Ln stands for heavy trivalent lanthanides (Tb-Lu) and $\mathrm{L}$ is malonate, have been synthesized. Simultaneous thermogravimetry and differential thermal analysis (TG-DTA), differential scanning calorimetry (DSC), X-ray powder diffractometry, infrared spectroscopy, TG-FTIR system, elemental analysis and complexometry were used to characterize and to study the thermal behaviour of these compounds. The dehydration of the compounds begins at $303 \mathrm{~K}$ and the anhydrous compounds are stable up to $548 \mathrm{~K}$. The results also provided information concerning the ligand's denticity, thermal behaviour and identification of some gaseous products evolved during the thermal decomposition of these compounds.
\end{abstract}

Keywords: heavy lanthanides, malonate, thermal behaviour.

\section{Introduction}

Lanthanide compounds have a numerous applications in various industrial and technological fields, in materials science, principally due to luminescence and/or magnetic properties. In search of new materials the malonate ions arouse a great interest because it exhibits a rather flexible stereochemistry at variable mode of binding with metal ion [1]. The malonate ions are employed in the controlled assembly of malonates and ions into strategies for supramolecular synthesis and crystal engineering purposes [2, 3], for designing complexes with desired magnetic properties $[3,4]$ and so on.

Preparation and investigation of several metal-ion malonates have also been investigated in the solid-state using thermoanalytical techniques, Xray diffractometry and infrared spectroscopy. The papers published are concerned with the influence of the lanthanide contraction in the dehydration of malonates in solid state, discussed on the basis of TG curves [5]; The onset temperatures of dehydration and decomposition which measures the relative stability of anhydrous and hydrated compounds varying according to some physical parameters of lanthanides and lanthanide malonates [6]; studies on double malonates (potassium rare earth malonates) $\mathrm{K}_{5} \mathrm{Ln}\left(\mathrm{C}_{3} \mathrm{H}_{2} \mathrm{O}_{4}\right)_{4}$ of gadolinium to holmium and yttrium [7]; study of thermal decomposition of transition metal malonates [8,9].

In this paper, the object of the present research was to prepare solid state compounds of heavy trivalent lanthanide ions (i.e. $\mathrm{Tb}$ to $\mathrm{Lu}$ ) with malonate and to characterize and to investigate by means of complexometry, elemental analysis, X-ray powder diffractometry, infrared spectroscopy, simultaneous thermogravimetry and differential thermal analysis (TG-DTA), differential scanning calorimetry (DSC) and TG-FTIR system. The thermal studies were performed in dynamical air atmosphere. 


\section{Experimental}

The sodium malonate monohydrated, $\mathrm{Na}_{2} \mathrm{CH}_{2} \mathrm{C}_{2} \mathrm{O}_{4} \cdot \mathrm{H}_{2} \mathrm{O}$ with $99.6 \%$ purity was obtained from Sigma, and aqueous solution of $0.1 \mathrm{~mol} \mathrm{~L}^{-1}$ was prepared, by direct weighing of the salt.

Lanthanide(III) chlorides were prepared from the corresponding metal oxides by treatment with concentrated hydrochloric acid. The resulting solutions were evaporated to near dryness; the residues were again dissolved in distilled water, transferred to a volumetric flask and diluted in order to obtain ca. $0.1 \mathrm{~mol} \mathrm{~L}^{-1}$ solutions, whose $\mathrm{pH}$ were adjusted to 5.0 by adding diluted sodium hydroxide solution.

The solid state compounds were prepared by adding slowly, with continuous stirring, the aqueous solutions of the ligand $\left(\mathrm{Na}_{2} \mathrm{CH}_{2} \mathrm{C}_{2} \mathrm{O}_{4}\right)$ to the respective metal chloride solutions until total precipitation of the metal ions. The precipitates were washed with distilled water until elimination of chloride ions, filtered through and dried on Whatman no. 42 filter paper and kept in desiccator over anhydrous calcium chloride.

In the solid state compounds hydration water, ligand and metal ion contents were determined from TG curves. The metal ions were also determined by complexometric tritrations with standard EDTA solution using xylenol orange, as indicator [10].

Carbon and hydrogen contents were determined by microanalytical procedures, with an EA 1110 CHNS-O Elemental Analyser from CE Instruments.

$\mathrm{X}$-ray powder patterns were obtained using a Siemens D-5000 X-ray diffractometer, employing $\mathrm{CuK} \alpha$ radiation $(\lambda=1.541 \AA)$ and a setting of $40 \mathrm{kV}$ and $20 \mathrm{~mA}$.

The attenuate total reflectance infrared spectra for sodium malonate, as well as for its metal-ion compounds were run on a Nicolet iS10 FTIR spectrophotometer, using an ATR accessory with Ge window.

Simultaneous TG-DTA and DSC curves were obtained with two thermal analysis system, model SDT 2960 and DSC Q10, both from TA Instruments. The purge gas was an air with a flow rate of $100 \mathrm{~mL}$ $\mathrm{min}^{-1}$ for TG-DTA and $50 \mathrm{~mL} \mathrm{~min}^{-1}$ for DSC experiments. A heating rate of $20 \mathrm{~K} \mathrm{~min}^{-1}$ was adopted, with sample masses about $7 \mathrm{mg}$ for TG-DTA and $2 \mathrm{mg}$ for DSC runs. Alumina and aluminium crucibles, the latter with perforated cover, were used for TG-DTA and DSC, respectively.

The measurements of the gaseous products were carried out using a Thermogravimetric
Analyzer Mettler TG-DTA coupled to a FTIR spectrophotometer Nicolet with gas cell and DTGS $\mathrm{KBr}$ detector. The furnace and the heated gas cell $(523 \mathrm{~K})$ were coupled through a heated $(\mathrm{T}=473 \mathrm{~K})$ $120 \mathrm{~cm}$ stainless steel line transfer with diameter 2 $\mathrm{mm}$ both purged with dry air $\left(50 \mathrm{~mL} \mathrm{~min}^{-1}\right)$. The FTIR spectra were recorded with 32 scans per spectrum at a resolution of $4 \mathrm{~cm}^{-1}$.

\section{Results and Discussion}

The analytical and thermoanalytical (TG) results of the synthesized compounds are shown in Table 1. These results permitted to establish the stoichiometry of these compounds, which is in agreement with the general formula: $\mathrm{Ln}_{2}\left(\mathrm{CH}_{2} \mathrm{C}_{2} \mathrm{O}_{4}\right)_{3} \cdot \mathrm{nH}_{2} \mathrm{O}$, where $\mathrm{Ln}=\mathrm{Tb}$ to $\mathrm{Lu}$ and $\mathrm{CH}_{2} \mathrm{C}_{2} \mathrm{O}_{4}$ is malonate, with $\mathrm{n}=7.5(\mathrm{~Tb}, \mathrm{Dy}, \mathrm{Ho})$ and 7 (Er, Tm, Yb, Lu).

\section{X-Ray Diffractometry}

The $\mathrm{X}$ - ray powder patterns Fig. 1 show that all the compounds have a crystalline structure without evidence for formation of an isomorphous series. The X-ray powder patherns also show that the final residues of these compounds are: $\mathrm{Tb}_{4} \mathrm{O}_{7}$ and $\mathrm{Ln}_{2} \mathrm{O}_{3}(\mathrm{Ln}=$ Dy to $\mathrm{Lu})$.

\section{FTIR of the compounds in the solid state}

The attenuate total reflectance spectroscopic data on malonate and its compounds with the metal ions considered in this work are shown in Table 2. The investigation was focused mainly within 1700$1400 \mathrm{~cm}^{-1}$ range because this region is potentially most informative in attempting to assign coordination sites.

In $\mathrm{Na}_{2} \mathrm{CH}_{2} \mathrm{C}_{2} \mathrm{O}_{4}$, strong band at $1582 \mathrm{~cm}^{-1}$ and a medium intensity band located at $1352 \mathrm{~cm}^{-1}$ are attributed to the anti-symmetrical and symmetrical frequencies of the carboxylate groups, respectively. The band assigned to the anti-symmetrical stretching carboxylate frequencies are shifted to lower values relative to the corresponding frequencies in $\mathrm{CH}_{2} \mathrm{C}_{2} \mathrm{O}_{4}$ itself (sodium salt) and $\Delta v(\mathrm{OCO})$ significantly less than ionic value. This behavior indicates that the coordination carried out through the carboxylate group [11] and the infrared spectra data suggests that the bonding of the carboxylate group to the metal is chelating bidentate and/or bridging in these com- 
Table 1. Analytical data for the $\mathrm{Ln}_{2} \mathrm{~L}_{3} \cdot \mathrm{nH}_{2} \mathrm{O}$ compounds

\begin{tabular}{|c|c|c|c|c|c|c|c|c|c|c|c|c|}
\hline \multirow{2}{*}{ Compounds } & \multicolumn{3}{|c|}{ Lanthanide oxide (\%) } & \multicolumn{2}{|c|}{ Ligand lost (\%) } & \multicolumn{2}{|c|}{ Water $(\%)$} & \multicolumn{2}{|c|}{ Carbon $(\%)$} & \multicolumn{2}{|c|}{ Hydrogen (\%) } & \multirow{2}{*}{$\begin{array}{c}\text { Final } \\
\text { Residue }\end{array}$} \\
\hline & Calcd. & TG & EDTA & Calcd. & TG & Calcd. & TG & Calcd. & EA & Calcd. & E. A. & \\
\hline $\mathrm{Tb}_{2} \mathrm{~L}_{3} \cdot 7.5 \mathrm{H}_{2} \mathrm{O}$ & 49.25 & 48.89 & 49.40 & 32.95 & 33.38 & 17.80 & 17.73 & 14.24 & 14.01 & 2.26 & 2.52 & $\mathrm{~Tb}_{4} \mathrm{O}_{7}$ \\
\hline $\mathrm{Dy}_{2} \mathrm{~L}_{3} \cdot 7.5 \mathrm{H}_{2} \mathrm{O}$ & 48.68 & 48.33 & 49.01 & 33.68 & 34.15 & 17.64 & 17.52 & 14.11 & 14.32 & 2.24 & 2.46 & $\mathrm{Dy}_{2} \mathrm{O}_{3}$ \\
\hline $\mathrm{Ho}_{2} \mathrm{~L}_{3} \cdot 7.5 \mathrm{H}_{2} \mathrm{O}$ & 49.00 & 48.95 & 48.65 & 33.47 & 34.00 & 17.53 & 17.05 & 14.02 & 13.80 & 2.23 & 2.11 & $\mathrm{Ho}_{2} \mathrm{O}_{3}$ \\
\hline $\mathrm{Er}_{2} \mathrm{~L}_{3} \cdot 7 \mathrm{H}_{2} \mathrm{O}$ & 49.88 & 49.38 & 49.50 & 33.67 & 33.85 & 16.45 & 16.77 & 14.10 & 13.89 & 2.11 & 2.34 & $\mathrm{Er}_{2} \mathrm{O}_{3}$ \\
\hline $\mathrm{Tm}_{2} \mathrm{~L}_{3} \cdot 7 \mathrm{H}_{2} \mathrm{O}$ & 50.10 & 49.85 & 49.80 & 33.52 & 33.56 & 16.38 & 16.59 & 14.03 & 14.35 & 2.10 & 2.35 & $\mathrm{Tm}_{2} \mathrm{O}_{3}$ \\
\hline $\mathrm{Yb}_{2} \mathrm{~L}_{3} \cdot 7 \mathrm{H}_{2} \mathrm{O}$ & 50.63 & 49.98 & 49.70 & 33.16 & 33.41 & 16.21 & 16.61 & 13.89 & 14.30 & 2.08 & 1.95 & $\mathrm{Yb}_{2} \mathrm{O}_{3}$ \\
\hline $\mathrm{Lu}_{2} \mathrm{~L}_{3} \cdot 7 \mathrm{H}_{2} \mathrm{O}$ & 50.87 & 50.09 & 50.62 & 33.00 & 33.53 & 16.13 & 16.38 & 13.82 & 13.50 & 2.07 & 1.90 & $\mathrm{Lu}_{2} \mathrm{O}_{3}$ \\
\hline
\end{tabular}

Ln trivalent lanthanides, L: malonate.

pounds [12]. The appearance of two $v_{\text {sym }}(\mathrm{OCO})$ bands in the spectrum of these compounds probably is due to different types of interaction between the carboxylate groups of malonate and lanthanide ions. This conclusion is supported at least in the case of the Dy compound by the results of the crystal structure determination [13].

Simultaneous TG-DTA curves of the compounds are shown in Fig.2. These curves exhibit mass losses in three or four consecutive steps and thermal events corresponding to these losses. A close similarity is noted concerning the TG-DTA profiles of these compounds.

These curves also show that the first mass loss occurs within the same temperature range for Tb, Dy, Ho and Tm compounds (i.e. $303-473 \mathrm{~K}$ ) and for Er, $\mathrm{Yb}$ and $\mathrm{Lu}$ ones (i.e. $303-453 \mathrm{~K}$ ), in spite of the compounds have been maintained in a forced circulation oven at $323 \mathrm{~K}$ during $12 \mathrm{~h}$ and removed to a desiccator over anhydrous calcium chloride. The second mass loss for all the compounds also begins at the same temperature $(548 \mathrm{~K})$, showing that the thermal behaviour up to this step is not dependent on the nature of the lanthanide ion. However the temperature range as shown by the next steps of thermal decomposition, as well as the mass lost in each step are characteristic of each compound.

For all the compounds the first mass loss that begin through a slow process followed by a fast one, associated to endothermic peak at $409-413 \mathrm{~K}$, is attributed to dehydration, which occurs in a single step. Once dehydrated, the anhydrous compounds are stable up to $548 \mathrm{~K}$, and above this temperature up to $653 \mathrm{~K}(\mathrm{~Tb}), 673 \mathrm{~K}$ (Dy, Ho, Er) and $693 \mathrm{~K}$ (Tm to $\mathrm{Lu})$, the mass losses corresponding to exothermic events are attributed to the oxidation of the organic matter. The similarity of the TG-DTA curves up to this point suggests that the decomposition mechanism is the same for these compounds.

For each of the considered compounds, the oxidation of the organic matter yields on intermediate derivative of carbonate, accompanied by a carbonaceous residue. The intermediate is probably the corresponding dioxycarbonate, as already observed for the compounds of phenyl-substituted derivatives of benzalpyruvates with trivalent lanthanides [14] and lanthanide malonates [6]. Tests with hydrochloric acid solution on samples heated up to the temperatures of formation of these intermediates, as indicated by the corresponding TG-DTA curves, confirmed in all cases evaluation of $\mathrm{CO}_{2}$ and presence of the carbonaceous residues.

The small mass loss observed above $673 \mathrm{~K}$ (Dy, Ho, Er) or $693 \mathrm{~K}(\mathrm{Tm}, \mathrm{Yb}, \mathrm{Lu})$, that occurs slowly, is attributed to the thermal decomposition of the carbonaceous residues. The small mass gain observed between 823 - $898 \mathrm{~K}(\mathrm{Er}), 813$ - $943 \mathrm{~K}$ $(\mathrm{Tm}), 798-910 \mathrm{~K}(\mathrm{Yb})$ and $803-948 \mathrm{~K}(\mathrm{Lu})$ is 


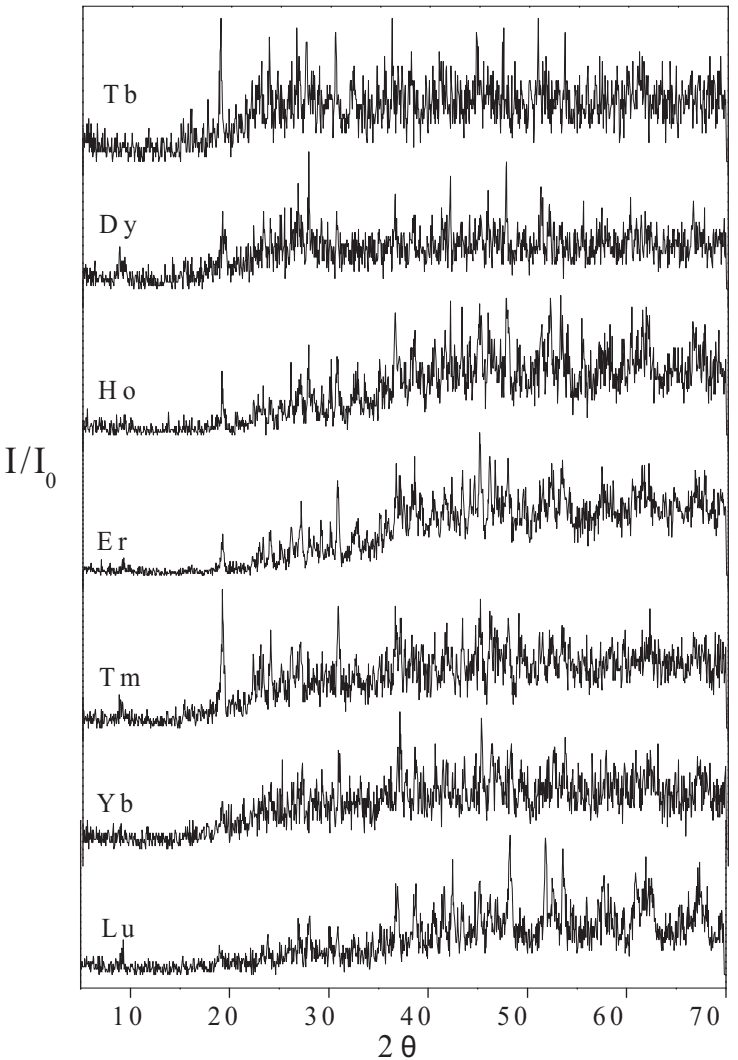

Figure 1. $\mathrm{X}$ - ray $-\mathrm{Tb}(\mathrm{L})_{3} \cdot 7.5 \mathrm{H}_{2} \mathrm{O}, \mathrm{Dy}(\mathrm{L})_{3} \cdot 7.5 \mathrm{H}_{2} \mathrm{O}$, $\mathrm{Ho}(\mathrm{L})_{3} \cdot 7.5 \mathrm{H}_{2} \mathrm{O}, \quad \operatorname{Er}(\mathrm{L})_{3} \cdot 7 \mathrm{H}_{2} \mathrm{O}, \quad \operatorname{Tm}(\mathrm{L})_{3} \cdot 7 \mathrm{H}_{2} \mathrm{O}$, $\mathrm{Yb}(\mathrm{L})_{3} \cdot 7 \mathrm{H}_{2} \mathrm{O}$ and $\mathrm{Lu}(\mathrm{L})_{3} \cdot 7 \mathrm{H}_{2} \mathrm{O}$. $(\mathrm{L}=$ malonate $)$. attributed to the formation of more derivative of carbonate due to the carbon dioxide evolved during the oxidation of the carbonaceous residues. No peak corresponding to the mass loss or gain is observed in the DTA curve, which is probably due to the small heat effect of these steps.

The mass loss above $793 \mathrm{~K}$ (Tb), $873 \mathrm{~K}$ (Dy, Ho), $898 \mathrm{~K}(\mathrm{Er}), 910 \mathrm{~K}(\mathrm{Yb})$ and $948 \mathrm{~K}(\mathrm{Tm}, \mathrm{Lu})$, corresponding to the exothermic followed by endothermic events (Tb-Er) or endothermic one $(\mathrm{Tm}-\mathrm{Lu})$ is attributed to the oxidation of the remaining carbonaceous residues and thermal decomposition of the intermediate derivative of carbonate, with formation of the respective oxides, $\mathrm{Tb}_{4} \mathrm{O}_{7}$ and $\mathrm{Ln}_{2} \mathrm{O}_{3}$ $(\mathrm{ln}=\mathrm{Dy}$ to $\mathrm{Lu})$. For Tm to $\mathrm{Lu}$, no exothermic event is observed, probably because of the small amount of carbonaceous residues remaining.

The mass losses or gain, temperature ranges and the peak or thermal event temperatures observed for each step of the TG-DTA curves are shown in Table 3.

The TG-DTA profiles, as well as the temperature range and the mass losses observed in each step of the TG curve are in disagreement with the results reported by Muraishi and co-workers [6]. These disagreements undoubtedly are due to the different experimental conditions, principally the static air atmosphere used to obtain the TG and DTA curves. For the dynamic atmosphere the evolved products of the thermal decompositions are continuously changed while in the static atmosphere the same is

Table 2. Spectroscopic data for sodium malonates $\left(\mathrm{Na}_{2} \mathrm{CH}_{2} \mathrm{C}_{2} \mathrm{O}_{4}\right)$ and compounds with heavy trivalent lanthanides.

\begin{tabular}{lccc}
\hline Compound & $v_{\text {as }}(\mathbf{C O O}) \mathbf{c m}^{-1}$ & $v_{\text {sym }}(\mathbf{C O O}) \mathbf{c m}^{-1}$ & $\Delta v\left(v_{\text {as }}-v_{\text {sym }}\right)$ \\
\hline $\mathrm{Na}_{2} \mathrm{~L} \cdot \mathrm{H}_{2} \mathrm{O}$ & $1582(\mathrm{vs})$ & $1352(\mathrm{~m})$ & 230 \\
$\mathrm{~Tb}_{2} \mathrm{~L}_{3} \cdot 7.5 \mathrm{H}_{2} \mathrm{O}$ & $1568_{\mathrm{f}}$ & $1378_{\mathrm{m}}$ & 190 \\
$\mathrm{Dy}_{2} \mathrm{~L}_{3} \cdot 7.5 \mathrm{H}_{2} \mathrm{O}$ & $1565_{\mathrm{f}}$ & $1376_{\mathrm{m}}$ & 189 \\
$\mathrm{Ho}_{2} \mathrm{~L}_{3} \cdot 7.5 \mathrm{H}_{2} \mathrm{O}$ & $1567_{\mathrm{f}}$ & $1375_{\mathrm{m}}$ & 192 \\
$\mathrm{Er}_{2} \mathrm{~L}_{3} \cdot 7 \mathrm{H}_{2} \mathrm{O}$ & $1569_{\mathrm{f}}$ & $1378_{\mathrm{m}}$ & 191 \\
$\mathrm{Tm}_{2} \mathrm{~L}_{3} \cdot 7 \mathrm{H}_{2} \mathrm{O}$ & $1570_{\mathrm{f}}$ & $1378_{\mathrm{m}}$ & 192 \\
$\mathrm{Yb}_{2} \mathrm{~L}_{3} \cdot 7 \mathrm{H}_{2} \mathrm{O}$ & $1572_{\mathrm{f}}$ & $1378_{\mathrm{m}}$ & 194 \\
$\mathrm{Lu}_{2} \mathrm{~L}_{3} \cdot 7 \mathrm{H}_{2} \mathrm{O}$ & $1573_{\mathrm{f}}$ & $1379_{\mathrm{m}}$ & 194 \\
\hline
\end{tabular}

$\mathrm{L}=$ malonate

$\mathrm{s}=$ strong; $\mathrm{m}=$ médium; $\mathrm{vs}=$ very strong

as (coo-) and vsym (coo-); anti-symmetrical and symmetrical vibrations of the coo- group, respectively 
Table 3. Temperature ranges $\Theta$, mass losses or gain (\%) and peak temperatures observed for each step of the TG-DTA curves of the compounds $\mathrm{Ln}_{2}(\mathrm{~L})_{3} \cdot \mathrm{nH}_{2} \mathrm{O}$, where $\mathrm{Ln}=$ heavy trivalent lanthanides and $\mathrm{L}$ is malonate.

\begin{tabular}{|c|c|c|c|c|c|}
\hline \multirow{2}{*}{ Compound } & & \multicolumn{4}{|c|}{ Steps } \\
\hline & & First & Second & Third & Fourth \\
\hline \multirow{3}{*}{$\mathrm{Tb}(\mathrm{L})_{3} 7.5 \mathrm{H}_{2} \mathrm{O}$} & $\theta \mathrm{K}$ & $303-473$ & $548-653$ & $793-1023$ & - \\
\hline & $\operatorname{loss}(\%)$ & 1.73 & 20.97 & 12.41 & - \\
\hline & Peak (K) & 413(endo) & 638(exo) & 853(exo) & - \\
\hline \multirow[t]{3}{*}{$\mathrm{Dy}(\mathrm{L})_{3} \cdot 7.5 \mathrm{H}_{2} \mathrm{O}$} & $\theta \mathrm{K}$ & $303-4733$ & $548-673$ & $673-823$ & $873-1053$ \\
\hline & loss $(\%)$ & 17.52 & 21.11 & 2.92 & 10.12 \\
\hline & Peak (K) & 413(endo) & 648(exo) & - & 908(exo), 917(endo) \\
\hline \multirow[t]{3}{*}{$\mathrm{Ho}(\mathrm{L})_{3} 7.5 \mathrm{H}_{2} \mathrm{O}$} & $\theta \mathrm{K}$ & $303-473$ & $548-673$ & $673-783$ & $873-1048$ \\
\hline & loss $(\%)$ & 17.05 & 22.28 & 2.57 & 9.15 \\
\hline & Peak (K) & 410(endo) & 648(exo) & - & 926(exo), 1013(endo) \\
\hline \multirow[t]{4}{*}{$\mathrm{Er}(\mathrm{L})_{3} \cdot 7 \mathrm{H}_{2} \mathrm{O}$} & $\theta \mathrm{K}$ & $303-473$ & $548-673$ & $673-898$ & $898-1023$ \\
\hline & loss $(\%)$ & 16.67 & 23.86 & 2.13 & 7.96 \\
\hline & gain $(\%)$ & - & - & 0.11 & - \\
\hline & Peak (K) & 412(endo) & 648(exo) & - & 941(exo), 1019 (endo) \\
\hline \multirow[t]{4}{*}{$\operatorname{Tm}(\mathrm{L})_{3} 7 \mathrm{H}_{2} \mathrm{O}$} & $\theta \mathrm{K}$ & $303-473$ & $548-693$ & $693-943$ & $943-1053$ \\
\hline & loss $(\%)$ & 16.59 & 24.76 & 1.59 & 7.21 \\
\hline & gain $(\%)$ & - & - & 0.33 & - \\
\hline & Peak (K) & 410(endo) & $655(\mathrm{exo})$ & - & 1023(endo) \\
\hline \multirow[t]{4}{*}{$\mathrm{Yb}(\mathrm{L})_{3} \cdot 7 \mathrm{H}_{2} \mathrm{O}$} & $\theta \mathrm{K}$ & $303-453$ & $548-693$ & $693-910$ & $910-1033$ \\
\hline & loss $(\%)$ & 16.61 & 25.48 & 0.98 & 6.95 \\
\hline & gain(\%) & - & - & 0.52 & - \\
\hline & Peak (K) & 409(endo) & 648(exo) & - & 1012(endo) \\
\hline \multirow[t]{4}{*}{$\mathrm{Lu}(\mathrm{L})_{3} \cdot 7 \mathrm{H}_{2} \mathrm{O}$} & $\theta \mathrm{K}$ & $303-453$ & $548-693$ & $693-948$ & $948-1053$ \\
\hline & loss $(\%)$ & 16.38 & 26.15 & 1.11 & 6.27 \\
\hline & - & - & - & 0.66 & - \\
\hline & Peak (K) & 410(endo) & 655(exo) & - & 1033(endo) \\
\hline
\end{tabular}

not observed. On that account the disagreements are observed.

The DSC curves of the compounds are shown in Fig. 3. These curves show endothermic and exothermic peaks that all are in agreement with the mass losses observed in the TG curves. Small differences observed concerning the peak temperatures obtained by TG-DTA and DSC are undoubtedly due to the perforated cover used to obtain the DSC curves, while TG-DTA ones are obtained without cover, beyond other experimental conditions that was not the same. 

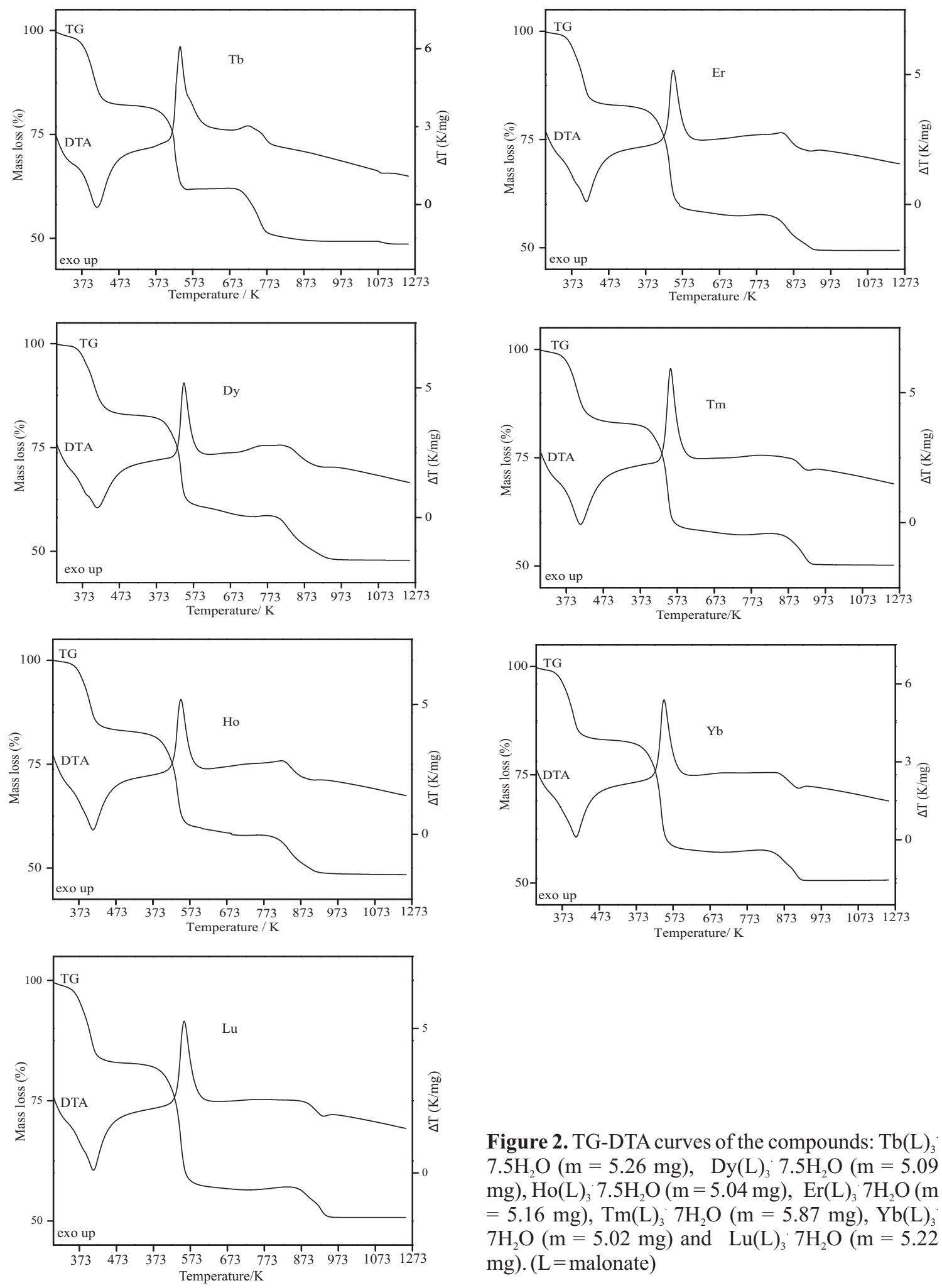

Figure 2. TG-DTA curves of the compounds: $\mathrm{Tb}(\mathrm{L})_{3}$. $7.5 \mathrm{H}_{2} \mathrm{O}(\mathrm{m}=5.26 \mathrm{mg}), \quad \mathrm{Dy}(\mathrm{L})_{3} \cdot 7.5 \mathrm{H}_{2} \mathrm{O}(\mathrm{m}=5.09$ $\mathrm{mg}), \mathrm{Ho}(\mathrm{L})_{3} \cdot 7.5 \mathrm{H}_{2} \mathrm{O}(\mathrm{m}=5.04 \mathrm{mg}), \mathrm{Er}(\mathrm{L})_{3} \cdot 7 \mathrm{H}_{2} \mathrm{O}(\mathrm{m}$ $=5.16 \mathrm{mg}), \operatorname{Tm}(\mathrm{L})_{3} \cdot 7 \mathrm{H}_{2} \mathrm{O}(\mathrm{m}=5.87 \mathrm{mg}), \mathrm{Yb}(\mathrm{L})_{3}$. $7 \mathrm{H}_{2} \mathrm{O}(\mathrm{m}=5.02 \mathrm{mg})$ and $\mathrm{Lu}(\mathrm{L})_{3} \cdot 7 \mathrm{H}_{2} \mathrm{O}(\mathrm{m}=5.22$ $\mathrm{mg}) .(\mathrm{L}=$ malonate $)$ 


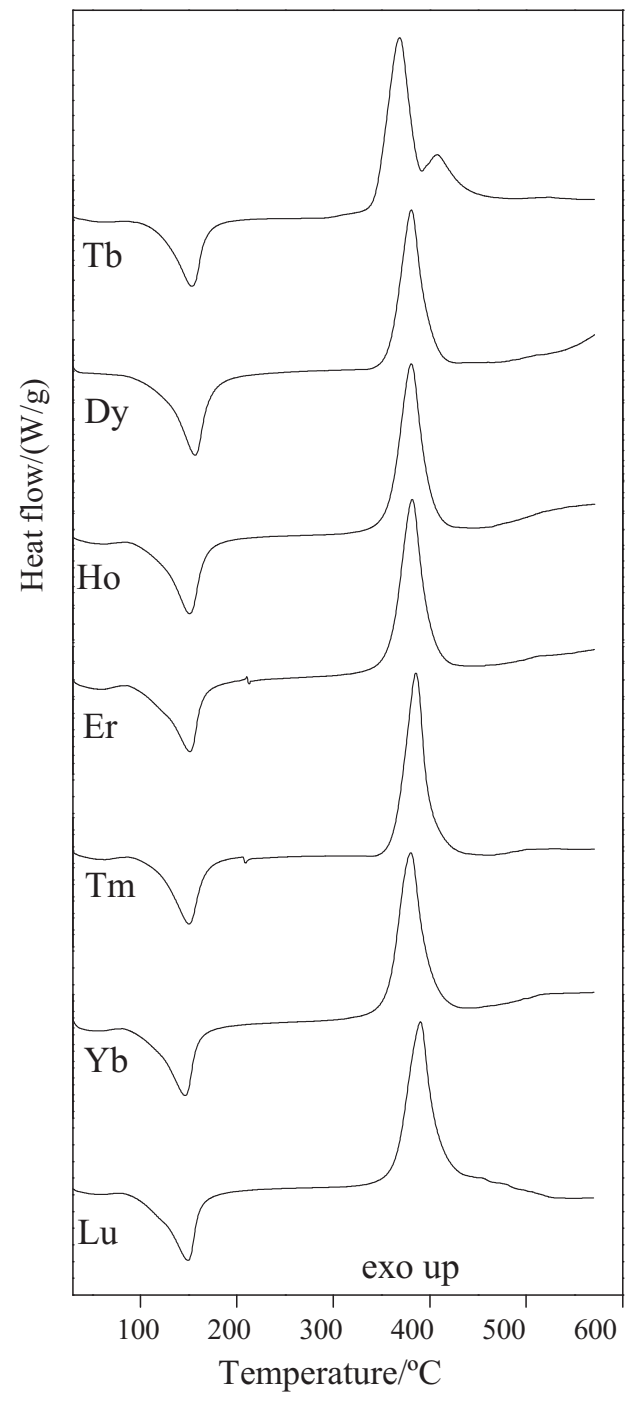

Figure 3. DSC curves of the compounds: $\mathrm{Tb}(\mathrm{L})_{3} \cdot 7.5 \mathrm{H}_{2} \mathrm{O}(\mathrm{m}=2.17 \mathrm{mg}), \quad \mathrm{Dy}(\mathrm{L})_{3} \cdot 7.5 \mathrm{H}_{2} \mathrm{O}$ $(\mathrm{m}=2.08 \mathrm{mg}), \mathrm{Ho}(\mathrm{L})_{3} \cdot 7.5 \mathrm{H}_{2} \mathrm{O}(\mathrm{m}=2.40 \mathrm{mg})$, $\mathrm{Er}(\mathrm{L})_{3} \cdot 7 \mathrm{H}_{2} \mathrm{O} \quad(\mathrm{m}=2.00 \mathrm{mg}), \quad \mathrm{Tm}(\mathrm{L})_{3} \cdot 7 \mathrm{H}_{2} \mathrm{O}$ $(\mathrm{m}=2.22 \mathrm{mg}), \mathrm{Yb}(\mathrm{L})_{3} \cdot 7 \mathrm{H}_{2} \mathrm{O}(\mathrm{m}=2.09 \mathrm{mg})$ and $\mathrm{Lu}(\mathrm{L})_{3} \cdot 7 \mathrm{H}_{2} \mathrm{O}(\mathrm{m}=2.10 \mathrm{mg}) .(\mathrm{L}=$ malonate $)$

The endothermic peaks within 420-430 K range are due to dehydration, which occurs in a single step. The dehydration enthalpies found for $\mathrm{Tb}$ to $\mathrm{Lu}$ compounds were: 357.2 , 366.3, 369.4, 363.5, 336.3, 368.8 and $388.1 \mathrm{~kJ} \mathrm{~mol}^{-1}$, respectively.
Monitoring of gaseous products by TG-FTIR system

The gaseous products evolved during the thermal decomposition in an air atmosphere of the compounds studied in this work were monitored by FTIR, and it has acetone and carbon dioxide as main product due to decarboxylation and oxidation of the organic matter. The IR spectra of the gaseous products evolved during the thermal decomposition of ytterbium malonate as representative of all the compounds are shown in Fig. 4. The spectra of the gaseous products evolved show peaks at $2360 \mathrm{~cm}^{-1}$, $2345 \mathrm{~cm}^{-1}$ and $666 \mathrm{~cm}^{-1}$, being the first two due to antisymmetrical stretching and scissoring (degenerated), respectively attributed to carbon dioxide. The peaks at $1737 \mathrm{~cm}^{-1}, 1366 \mathrm{~cm}^{-1}$ and $1215 \mathrm{~cm}^{-1}$, corresponding to axial deformation of $\mathrm{C}=\mathrm{O}$, angular symmetric deformation of $\mathrm{CH}_{3}$ and axial and angular deformation of $\mathrm{C}-\mathrm{CO}-\mathrm{C}$, respectively are attributed to acetone.

\section{Conclusion}

From TG, complexometry and elemental analysis data, a general formula could be established for the compounds involving heavy lanthanides ions. The X-ray powder patterns pointed out that the synthesized compounds have a crystalline structure and the infrared spectroscopic data suggests that $\mathrm{CH}_{2} \mathrm{C}_{2} \mathrm{O}_{4}$ acts as a chelating bidentate and/or briding bidentate ligand towards the metal ions considered in this work.

The TG-DTA and DSC curves provided previously unreported information about the thermal stability and thermal decomposition of these compounds in dynamic air atmosphere.

The gaseous evolved during the thermal decomposition of the compounds have acetone, $\mathrm{CO}_{2}$ and $\mathrm{CO}$ as main products.

\section{Acknowledgements}

The authors thank, AFA, FAPESP, CNPq and CAPES Foundations for financial support. 


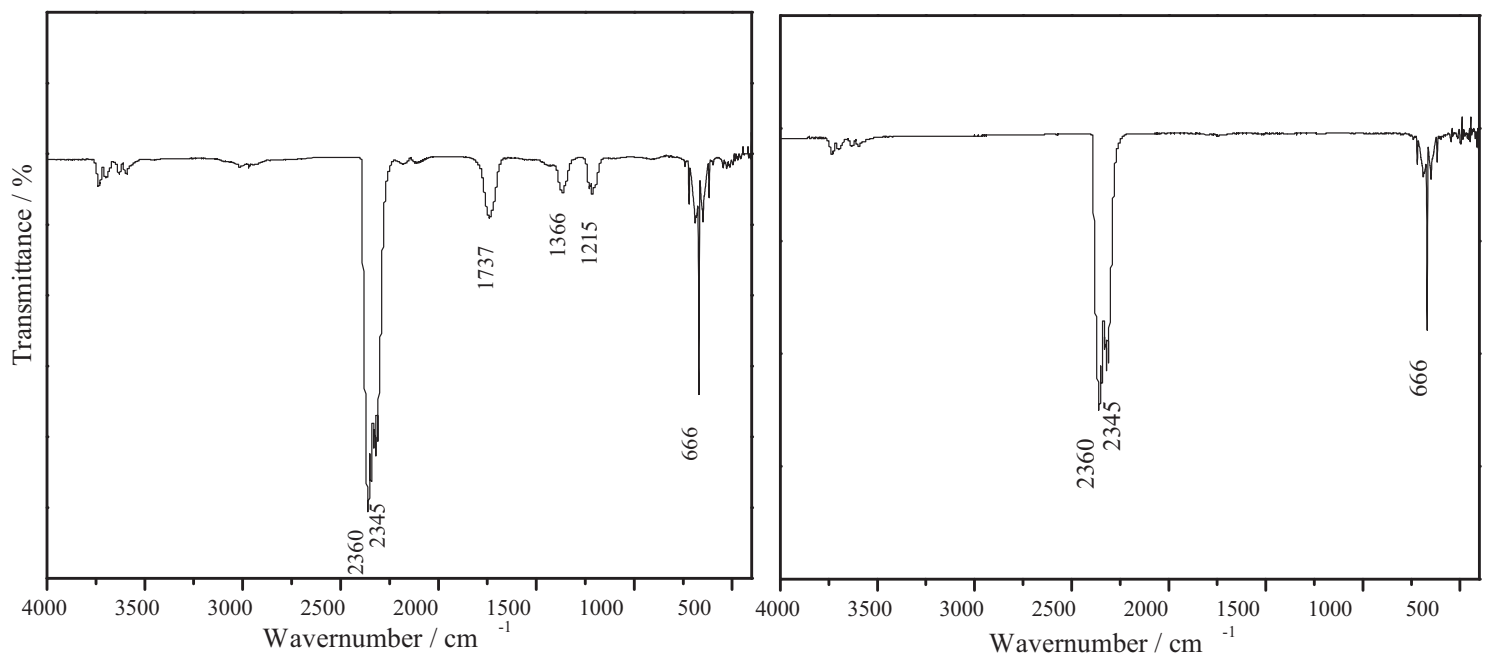

Figure 4. FTIR spectra of gaseous products evolved during the decomposition of the ytterbium malonate, as representative of the all compounds.

Resumo: Compostos Ln-L no estado sólido, em que Ln representa os lantanídeos trivalentes ( $\mathrm{Tb}-\mathrm{Lu})$ e Lé malonato, foram sintetizados neste trabalho. A termogravimetria e análise térmica diferencial simultânea (TGDTA), calorimetria exploratória diferencial (DSC), difratometria de raios X pelo método do pó, espectroscopia na região do infravermelho (FTIR), TG-FTIR, análise elementar e complexometria foram utilizadas para caracterizar e estudar o comportamento desses compostos. A desidratação desses compostos começa em $303 \mathrm{~K}$ e os compostos anidros são estáveis até $548 \mathrm{~K}$. Os resultados também proporcionaram informações com respeito à denticidade do ligante, comportamento térmico e a identificação de alguns produtos gasosos eliminados durante a decomposição térmica desses compostos.

Palavras-chave: lantanídeos pesados, malonato, comportamento térmico.

\section{References}

[1] A. Karipides, J. Ault, A. Thomas Reed, Inorg Chem. 16(1977) 3299.

[2] H-Y. Shen, W-M. Bu, D-Z. Liao, J-H Jiang, SP. Yan, G-L. Wang, Inorg Chem Commun. 3 (2000) 497.

[3] Rodriguez-Martin Y, Ruiz-Pérez C, Sanchiz J, Lloret F, Julve M, Inorg Chim Acta 318 (2001)159.

[4] Y. Rodriguez-Martin, M. Hernandez-Molina, F. S. Delgado, J. Pasan, C. Ruiz-

Perez, J. Sanchiz, F. Lloret, M. Julve, Cryst Eng Comm. 4(2002) 522.

[5] K. Muraishi, K. Nagase, M. Kikuchi, K. Sone, N. Tanaka, Cryst Eng Comm. 55 (1982) 1845.

[6] K. Muraishi, Thermochim. Acta 182 (1991) 209.

[7] M. A. Nabar, B. N. Jukar, T Bull Chem Soc Jpn. $58(1985) 3582$.
[8] F. J. Caires, L. S. Lima, C. T. Carvalho, M. Ionashiro, Thermochim. Acta 497 (2010) 35.

[9] B. S. Randhawa, K. Gandotra, J. Therm. Anal. Cal. 85 (2006) 417.

[10] M. Ionashiro, C. A. F. Graner, J. Zunon Netto, Eclet. Quím. 8(1983) 29.

[11] K. Nakamoto, Infrared and Raman spectra of inorganic and coordination compounds, Part B, 5th ed. New York: Wiley; 1997.[12] G B Deacon, R. J. Phillips, Coord. Rev. 33 (1980) 227.[13] F. ZhanQiang, Z. Rong-Hua, S. Zhao-Feng, Meiy, Acta Crysl. E64 (2008) m 877.[14] E. Y. Ionashiro, G. Bannach, A. B. Siqueira, C. T. Carvalho, E. C. Rodrigues, M. Ionashiro, J. Therm. Anal. Cal. 92 (2008) 953. 